\title{
THE AMAZÔNIA AND THE GLOBAL CLIMATE
}

L.C.B.Molion'

\section{ABSTRACT}

The Amazônia, the largest river basin of the world covered mostly with natural rainforest, is a fast changing environment. Only during the dry season of 1987, 20 million hectares of land were burnt of which $40 \%$ were estimated to be natural forests. Changing the land use from forests to other types, such pasture or agricultural fields, may interfere with the global climate besides altering drastically the local environment. First, because the Amazônia is an important heat source for the general circulation of the atmosphere and second because the forest plays significant role in the chemical composition of the atmosphere and in the greenhouse effect. This paper attempts to demonstrate this fact using the evidence available presently.

\section{INTRODUCTION}

The climate of a region is determined by factor acting on both global and regional scales. The most important are the general circulation of the atmosphere acting on the region, the local topography, the nature of surface cover, the hydrological cycle and the influence of ocean currents if the region is coastal. The general circulation of the atmosphere, which is a consequence of the latitudinal distribution of solar energy and the asymmetric distribuition of land and oceans, imposes the general characteristics of a region's climate. The hydrological cycle is not only a component of climate itself but also of the biogeophysical landscape; its influence on climate is more than the interaction between the atmospheric moisture, rainfall and runoff.

\footnotetext{
${ }^{1}$ Instituto de Pesquisas Espaciais, INPE, 12201-São José dos Campos, SP, Brazil.
} 
The latitudinal belt $10^{\circ} \mathrm{N}-10^{\circ} \mathrm{S}$ covers about 88 million square kilometers of the Earth's surface of which $77 \%$ are oceans and $23 \%$ continents, the latter presenting $50 \%$ covered with natural forests. The largest of all is the Amazônia which corresponds to approximately $8 \%$ of the belt and $34 \%$ of the land surface within it. With such an areal extention covered with humid tropical forests, the Amazônia may be important for the global climate. This paper aims to demonstrate this fact based on the present knowledge for forest-atmosphere interactions, both physical and chemical. It also reviews the possible impacts on the global and regional climate that large scale deforestation may produce and present some solutions for the social and economical development of the region.

\section{AMAZÓNIA: A HEAT SOURCE FOR THE ATMOSPHERE}

The solar energy reaching the surface is primarily used for evaporating water (latent heat) and heating the air (sensible heat). In Central Amazônia, micrometeorological studies (MOLION, 1987) have shown that about $80 \%$ of the avallable energy is used in evapotranspiration (evaporation + plant transpiration), the rest warms the air. Over "terra firme" forest, that is upland forest which is never flooded, the water vapor flux is basically constituted of $60 \%$ transpiration of plants and $40 \%$ of rainfall water intercepted by forest canopy and litter layer. Direct soil evaporation is negligible. In the annual mean, evaporation in Amazônia is about $50 \%$ of the total rainfall, that is, considering the climate stable, in the long range half of Amazônia's rainfall comes from local evaporation and the other half from the Atlantic Ocean (MOLON, 1976 and SALATI, 1987). This local contribution is considered high compared to what occurs in temperate latitudes where it is estimated that local evaporation contributes about $10 \%$ to local precipitation. When the water vapor condenses forming clouds and rain it releases the heat (latent heat) that was used in the evapotranspiration process.

Over a tropical continent the warm and moist air rises (convection) and it is replaced in the low level by air coming from the oceans (convergence); in the high troposphere the air is transported away (divergence) from the continent and sinks over the subtropical oceans thus closing a circulation cell. Figure 1, extracted from MOUON (1987) sketches this direct circulation cell. For didactical purposes only, the direct circulation is broken into two components: the east-west component known as Walker Circulation and the equator-tropics component called Hadley Circulation. Figure 2 shows schematically these two circulation cells which are major components of the general circulation of the atmosphere. Note that along the equatorial belt there are three regions where there is ascending motion (Fig. 2a): the "Maritime Continent" (Indonesia and North of Australia), the Congo River Basin and the Amazonas River Basin. These regions are sources of heat to GCA, the latter two being of continental origin, Figure 1 type of mechanism. The first one is of a different nature; it is a result of heat transfer from the ocean to the atmosphere as the 


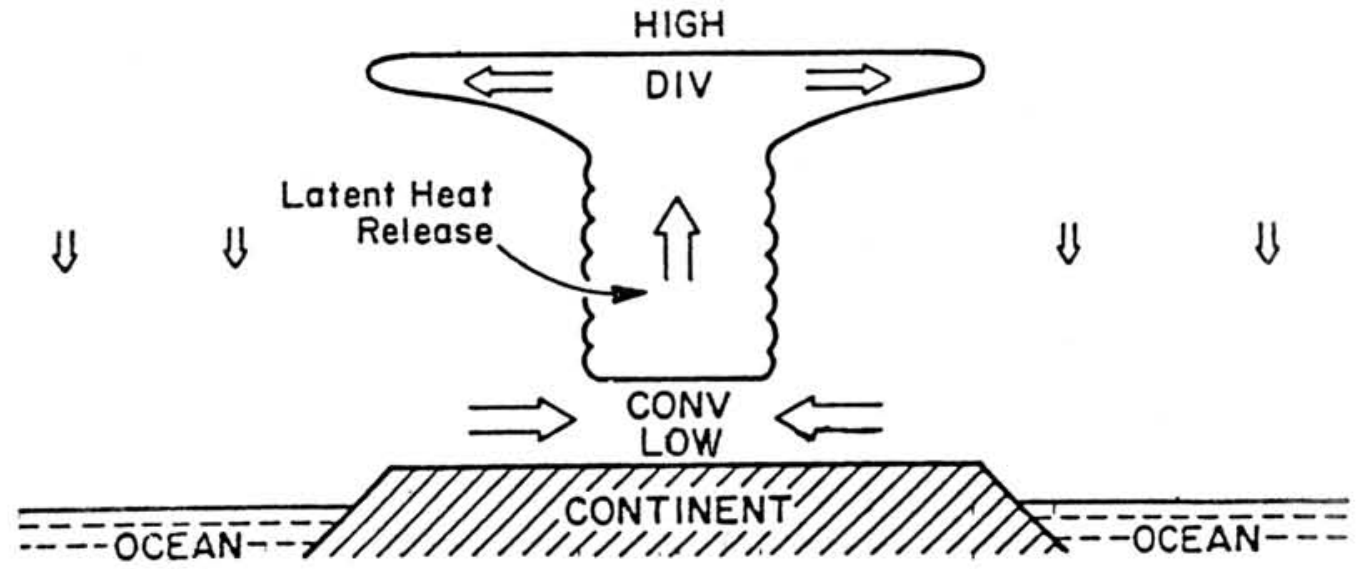

Figure 1 - Schematic diagram of a direct circulation cell resulting from differential heating between the continent and the adjacent oceans in the summer (MOLON, 1987).

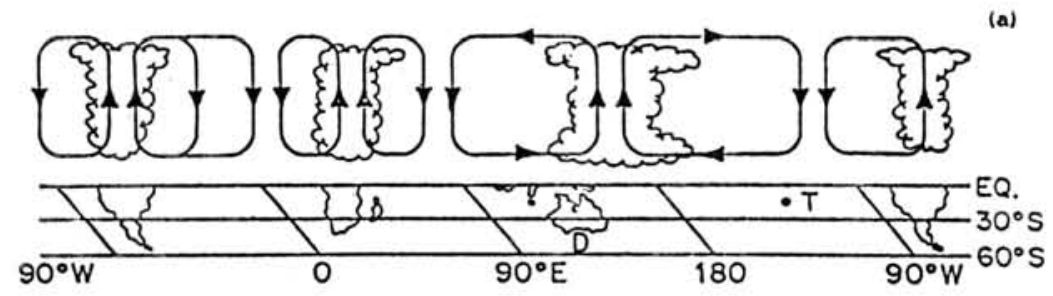

(b)

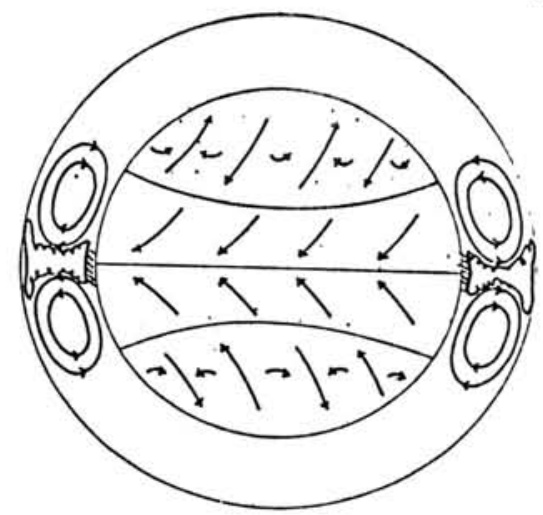

Figure 2 - Schematic diagram (a) of the mean Walker Circulation cell and (b) of the Hadley Circulation cell. 
Pacific waters in that region have surface temperatures of $28^{\circ} \mathrm{C}$ or higher. The Congo heat source is the weakest of the three; the "Maritime Continent" source appears to be stronger than the Amazônia. There are years, however, that the Amazonian is more powertul than the other (see, e.q., KASAHARA \& MIZZI, 1983). The latent heat released by these sources is transported away from the tropics by the GCA to temperate and polar regions which present a deficit of heat because they receive less energy from the sun than lose to outer space. This way, the global climate remains stable, nevertheless presenting annual variations which may be tied up to the fluctuating power of the sources.

The Amazônia is, therefore, an important source of heat for the GCA. A large scale deforestation may reduce the power of this source. As mentioned previously, about $50 \%$ of Amazonian average rainfall comes from water vapor which is evaporated locally; during GTE/ABLE-2 wet season campaign in fact NOBRE et al. (1988) concluded that $58 \%$ of the rainfall came from local evapotranspiration; deforestation is known to reduce evapotranspiration, therefore reducing precipitation and latent heat release. Using a global circulation model (GCM), DICKINSON \& HENDERSON-SELERS (1988) performed a large scale deforestation experiment for the Amazônia. They concluded that there was about $20 \%$ reduction in rainfall over the basin. The consequent reduction in latent heat release correspond to about $5 \%$ of the total heat transported poleward across latitudes $10^{\circ} \mathrm{N}$ and $10^{\circ} \mathrm{S}$ according to data published in HASTENRATH (1985). With a large scale deforestation in Amazônia, therefore, the extratropics may receive less heat and become cooler than are today, everything else remaining constant. One of the possible consequence of the cooling is the reduction of the growing season and thus of grain production. Besides that cooling the poles may onset a new ice age. Although the arguments are physically sound, the deforestation effect on the global climate is a controversial issue, mainly because numerical models used for testing hypotheses of climatic changes are in their infancy yet and therefore their results must be interpreted with care.

\section{THE AMAZÓNIA AND THE CHEMICAL COMPOSITION OF THE ATMOSPHERE}

The atmosphere of the Earth is constituted of gases which allow solar radiation to pass through but absorb heat radiated by the surface. This property of the atmosphere is called "greenhouse effect" and the main absorbers of infrared radiation are water vapor, carbon dioxide $\left(\mathrm{CO}_{2}\right)$, ozone $\left(\mathrm{O}_{3}\right)$, methane $\left(\mathrm{CH}_{4}\right)$ and the ChloroFluoroCarbon (CFC) compounds.

The role that tropical forests have on the chemical composition of the atmosphere is not known quantitively yet. It is said that they are important sources of methane and carbon monoxide (CO). The $\mathrm{CH}_{4}$ is produced by the decomposition of organic matter in lakes, marshes and in floodplains; the $\mathrm{CO}$ is mainly produced by biomass burning. Both $\mathrm{CO}$ and $\mathrm{CH}_{4}$ are oxydated through different catalitic processes 
which involve nitrogen oxides (NOx) also produced by biomass burning. With high concentrations of NOx, ozone is produced and with low concentration of NOx ozone is destroyed. CRUTZEN (1987) showed that the vertical distribution of tropospheric ozone were high over Brazilian savannas ("Cerrados") in Central Brazil than over the Amazônia during the dry season. He attributed this fact to the higher number of fires in the Cerrados with consequent photochemical production of ozone, which can be transported to high troposphere by the tall $\mathrm{Cb}$ clouds and then to other parts of the world through atmospheric circulation of the type Hadley-Walker cell.

To study the influence that the Amazonia forest exerts on the chemical composition of the atmosphere, two campaigns of GTE/ABLE were made, one during the dry season, July-August 1985 (HARRISS et al., 1988) and another during the wet season, April-May 1987 (HARRISS et al., 1988). Data are being analysed currently, but there are already some interesting results reported. For instance, it was found that the forest is a sink of tropospheric ozone and the region as a whole is a source of methane; also that the forest has a net absorption of $9 \mathrm{~kg}$ of carbon per hectare per day through photosynthesis (SONG MIAO, 1988). If only half of Amazônia remains forested, than is about 3.5 million square kilometers of "terra firme" forests, this would be sufficient to fix from the atmosphere through fossil fuel burning, estimated to be 5 billion metric tons. The burning of forest, on the other hand, would contribute to the increase of $\mathrm{CO}_{2}$ concentrations. During the dry season of 1987, SETZER (1988) using satellite images estimated that 20 million hectares of land were burnt in the Legal Amazônia, of which $40 \%$ at least were natural forests; those fires produced about 600 million metric tons of carbon, that is about $10 \%$ of the total carbon released globally every year. The Amazônia has a storage of biomass equivalent to 50 billion metric tons of carbon which, if burnt, would increase $\mathrm{CO}_{2}$ concentration by 3 to $5 \mathrm{ppm}$ (FEARNSIDE, 1985). Deforestation of Amazônia, then, contributes to the enhancement of the greenhouse effect in two ways: first, not too expressive, by biomass burning and second by destroying the trees which fix carbon through photosyntesis. On the other hand, rising of sealevels, as result of warming the climate, would have a damming effect on the Amazonas River discharge which will tend to flood permanently parts of its floodplains, areas most suitable for sustaining agriculture in the region.

\section{DEFORESTATION LOCAL EFFECTS}

Forested regions have lower albedo (surface reflective) than regions with different land use types. Therefore, they absorb more solar radiation and have more energy to be partitioned between latent and sensible heat. In Amazônia, in particular, about $80 \%$ of the available energy is used for evapotranspiration in average and only $20 \%$ go in heating the air. Changing from forest to other land use types modifies this energy partitioning. The general result is that the amount used in heating the air 
increases and the one that go into evapotranspiration is reduced. Removal of the forest, therefore, leads to an increase in the temperature amplitudes, that is the maximum temperatures increase whereas the minimum decrease. GHUMAN \& LAL (1987) reported results of a comparative study in Nigeria between a forest and an adjacent deforested area. They observed over the deforested area that the soil temperature amplitude at $1 \mathrm{~cm}$ depth was $5^{\circ} \mathrm{C}$ higher than that of the forest soil. During the day, the mean air temperature, measured at 1 meter level, were $3^{\circ}$ to $6^{\circ} \mathrm{C}$ higher in the clearing than in the forest; at night, however, the forest air temperature was slightly higher than that over the clearing. The relative humidity also showed large contrasts between the forested and deforested areas. For a particular day, the observed minimum relative humidities were $87 \%$ and $49 \%$ for the forest and the clearing, respectively, the distance between the two measuring point being about 50 meters.

Simulations made with climate model (DICKINSON \& HENDERSON-SELLERS, 1988) suggested that soil surface temperature would increase by $2^{\circ}$ to $5^{\circ}$ whereas air temperature at 2 meter level increase would be 1 to $3^{\circ} \mathrm{C}$. At the same time, there may be a reduction in evapotranspiration with consequent reduction of local precipitation because, as pointed out before, $50 \%$ of the Amazonian rainfall are made of local evapotranspiration. In the same study, Dickinson and Henderson-Sellers indicated that, at places where there are high precipitation rates, the evapotranspiration suffered up to $50 \%$ reduction and, in turn, the average precipitation in the basin was reduced by about $20 \%$. They also suggest that a large scale deforestation may change both temporal and spatial rainfall distribution.

Another important component of the hydrological balance is the runoff, which paradoxically may increase with the reduction of precipitation, showing higher flood peaks. The main causes of increased runoff after deforestation are soil compaction reducing infiltration and the increased amount of rainfall that reaches the soil. As pointed out before, the Amazon forest canopy intercepts in average about $15 \%$ of the rainfall, that is this percentage does not reach the soil surface; with the removal of the forest cover in Central Amazônia there will be an increase of about 4 thousand cubic meters of water per hectare per year which, due to soil compaction by animals and machines, will runoff directly to river channels. The moisture stored in the soil would be reduced drastically with deforestation. Therefore, during the dry season, and dry periods which occur in the wet season, there will be a tendency of increasing the frequency of plant water stress. Conventional agriculture, then, may need irrigation.

Another problem linked to the variation of the climatic elements and the removal of forests is the soil degradation and consequent erosion. JANSSON (1982) reviewed the existent literature on tropical soil erosion and found rates up to 334 ton/ha per year. Erosion for cultivated fields in the tropics may vary of factors which go from 1.5 to 2500 times the erosion rates of forested areas depending upon the slope of the terrain, soil textures, annual rainfall, nature and techniques of cultivation among others. Soil is an essencial component for development of the biosphere; its formation is very slow and takes a time longer than human life to recover once destroyed. Once the forest protective cover is removed the machanical 
impact of large raindrops disaggregate the superficial structure of the soil. The resultant small particles seal the pores and reduce even more the infiltration of the soil already compacted by agriculture. At the same time, the amount of rainfall which was previously intercepted by the canopy reaches the soil. The consequence is an increased surface runoff and erosion with associated silting of rivers and reservoirs, changing of water quality and aquatic life.

\section{CONCLUSION}

If a population growing rate of $2 \%$ a year is considered, one finds that in the middle of next century the world may have 12 billion inhabitants. It is obvious then that tropical regions such as Amazônia, where in principle there are no climatic limiting fractors for the production of food, even considering future scenarios predicted due to enhanced greenhouse effect, should not remain marginal to this process. The development of the regions, however, should be rational and careful since there are arguments pointing out that its forests cover is very important for the stability of the global climate as well as for the local environment. Considering the previous discussion the natural question is: What is the most appropriate land use for Amazônia? MOUON (1986) proposed solutions for land use in the tropics. In summary, he concludes that the best solution seems to be a balance of natural forests, agricultural and pasture fields, being a higher proportion of forest and small of pastures.

\section{REFERENCES}

CRUTZEN, P.J. (1987) Role of the tropics in atmospheric chemistry. In: DICKINSON, R.E. (ed.) The Geophysiology of Amazónia. New York, John Wiley and Sons. p.107-132.

DICKINSON, R.E. \& HENDERSON-SELERS, A. (1988) Modeling tropical deforestation: a study of GCM land-surface parameterization. Quarterly Journal Royal Meteorological Society.

FEARNSIDE, P.M. (1985) Brazil's Amazon Forest and the global carbon problem. Interciência, 10(4):179185.

GHUMAN, B.S. \& LAL, R. (1987) Effects of deforestation on soil properties and microclimate of a high rainforest in Southern Nigeria. In: DICKINSON R.E. (ed.) The Geophysiology of Amazônia. New York, John Wiley and Sons. p.225-244. 
HARRISS, R.C.; GARSTANG, M.; WOFSY, S.C. (1988a) The Amazon boundary layer experiment (ABLE.2B): wet season 1987. EOS Transactions, American Geophysical Union, 69(16):318.

HARRISS, R.C.; WOFSY, S.C.; GARSTANG, M.; BROWEU, E.V.; MOUON, LC.B.; McNEAL, R.J.; HOEL, J.M.; BENDURA, R.J.; BECK, S.M.; NAVARRO, R.L; RILEY, J.T.; SNEL, R.L (1988b) The Amazon boundary layer experiment (ABLE-2A): dry season 1985. Journal Geophysical Research, 93(D2):1351-1375.

HASTENRATH, S. (1985) Climate and circulation of the tropics. Dordrecht, D.Reidel Publ. 455p.

JANSSON, M.B. (1982) Land erosion by water in different climates. UNGI Report $n^{2} 57$, Dept. Physical Geography, Uppsala University, Sweden.

KASAHARA, A. \& MIZZl, A.P. (1983) On the evaluation of the heating/cooling rate from the ECMWF level IIIb analysis data. The Global Weather Experiment Newsletter n² 2, USC-GARP, NAS, Washington, D.C.

MOLON, L.C.B. (1976) A climatonomic study of the energy and moisture fluxes of Amazonas basin with consideration of deforestation effects. São José dos Campos, INPE 40p. (Relatório 923TPT/035).

MOLON, LC.B. (1986) Land use and agrosystem management in the humid tropics in land use and agrosystem management under severe climatic conditions, WMO Technical Rept. ne 184, WMO, Geneva, Switzerland, p.114-137.

MOLON, LC.B. (1987) Micrometeorology of an Amazonian rainforest. In: DICKINSON, R.E. (ed.) The Geophysiology of Amazônia. New York, John Wiley \& Sons. p.255-270.

NOBRE, C.A.; DIAS, P.LS.; SANTOS, M.A.R.; COHEN, J.; ROCHA, P.J.; GUEDES, R.; FERREIRA, R.N.; SANTOS, I.A. (1988) Mean large scale meteorological aspects of ABLE-2B. EOS Transactions. American Geophysical Union, 69(16):318.

SALATI, E. (1987) The forest and the hydrological cycle. In: DICKINSON, R.E. (ed.) The Geophysiology of Amazônia. New York, John Wiley \& Sons. p.273-296.

SETZER, A.W.; PEREIRA, M.C.; PEREIRA Jr., A.C.; ALMEIDA, S.A.O. (1987) Relatório de Atividades do 
Projeto IBDF-INPE "SEQE". São José dos Campos, INPE. 47p. (Relatório 4534/RPE/565).

SONG MIAO, P.S.; BAKWIN, P.S.; WOFSY, S.C.; FITZJARRALD, D.R.; CABRAL, O.M.R. (1988) Uptake of $\mathrm{CO}_{2}$ and $\mathrm{O}_{3}$ by the Amazon forest in the wet season. EOS Transactions. American Geophysical Union, 69(16):320. 